2018-09

Pan-Mediterranean Holocene vegetation and land-cover dynamics from synthesised pollen data

\title{
Woodbridge-Fisher, J
}

http://hdl.handle.net/10026.1/11681

\subsection{1/jbi.13379 \\ Journal of Biogeography \\ Wiley}

All content in PEARL is protected by copyright law. Author manuscripts are made available in accordance with publisher policies. Please cite only the published version using the details provided on the item record or document. In the absence of an open licence (e.g. Creative Commons), permissions for further reuse of content should be sought from the publisher or author. 
Uncorrected author's copy of the accepted manuscript

Acceptance date: 5 May 2018

Cite as:

Woodbridge J, Roberts CN and Fyfe RM (2018) Pan-Mediterranean Holocene vegetation and landcover dynamics from synthesised pollen data Journal of Biogeography DOI: 10.1111/jbi.13379 
1 Article type: Original Article

2

Pan-Mediterranean Holocene vegetation

4 and land-cover dynamics from synthesised pollen data

5

6 Jessie Woodbridge, Neil Roberts and Ralph Fyfe

7

8 School of Geography, Earth and Environmental Sciences, Plymouth University, Drake

9 Circus, Plymouth, UK

10

11 Corresponding author: Jessie Woodbridge: Plymouth University, Drake Circus, Plymouth, 12 UK. jessie.woodbridge@plymouth.ac.uk

13

14 Word count: 7043

15

16

17

18

19

20

21

22

23

24

25 


\section{ABSTRACT}

27

28 Aim

29 The Mediterranean is characterised by diverse and spatially-heterogeneous mosaic landscapes. Within this study a cluster analysis-based method is developed for the classification of Mediterranean vegetation types based on modern and fossil pollen datasets. The application of this approach to multiple pollen records spanning the Mediterranean region has allowed temporal variations in vegetation dynamics to be explored throughout the

34 Holocene. We ask how far back stable baseline vegetation communities can be identified in the pollen record, and whether those types considered to be characteristic of the Mediterranean landscapes have been present in the past as well as at the present.

\section{Location}

The research location includes the land areas surrounding the Mediterranean Sea. The pollen sites are principally located in mainland Spain, southern France, Greece and Turkey, Italy, North Africa, the Levant, and some Mediterranean islands.

\section{Methods}

425641 samples from 158 fossil pollen records (cores) and 1799 modern pollen surface samples

43 were harmonised taxonomically and pollen count data summed into 200-year time windows on a common timescale from 11,000 BP to the present-day. Cluster analysis and community classification was used to identify major vegetation types along with other approaches to explore patterns in ecological datasets, such as Simpson’s diversity index and non-metric

47 multidimensional scaling.

\section{$48 \quad$ Results}

49 The pollen datasets were classified into eleven closed forest/woodland and five open or scrubland vegetation types. Closed vegetation clusters declined from the mid-Holocene with 
51 a marked increase in open or human-modified vegetation types since 3500 BP and with an

52 increasing rate of vegetation change and habitat diversity through time.

\section{Main conclusions}

54 The Mediterranean has been a dynamic landscape throughout the Holocene with frequent 55 changes in land cover identified in the pollen datasets. The pollen-inferred clusters reveal a

56 wider range of Mediterranean vegetation types than identified in previous studies; for

57 example, including both beech and alder woods. Evergreen Oleaceae-dominated shrubland is

58 much better represented in modern than in fossil samples while mesic forest was abundant in

59 the past but is uncommon today.

60

61 Keywords: Disturbance; Holocene; Human impacts; Land-cover; Landscape structure;

62 Mediterranean; Pollen; Vegetation

63

64 


\section{INTRODUCTION}

Pollen analysis offers a valuable tool for exploring long-term changes in vegetation and land cover (Jackson \& Blois 2014; Edwards et al., 2017). Numerous studies have mapped and classified European vegetation using fossil pollen for discrete time intervals through the Holocene in relation to climate and major environmental gradients (e.g. Huntley, 1990; Prentice et al., 1996; Peyron et al., 1998). This has led to the description of plant functional types, the identification of 'biomes' and their spatial and temporal distribution (e.g. Marinova et al., 2017), climate reconstruction based on pollen and vegetation modelling (e.g. Guiot \& Kaniewski, 2015) and geographical mapping of individual taxa (Brewer et al., 2017).

Understanding patterns of vegetation dynamics and biogeographic change allows improved knowledge of the habitats within ecoregions and their responses to disturbance and environmental change, which can provide frameworks for biodiversity conservation policies and ecological modelling (Blasi et al., 2014). Previous studies have often focused on continental scales. For example the ‘BIOME 6000’ mapping project (Prentice et al., 1996; Prentice \& Webb, 1998) provided a pollen-based landscape reconstruction for Europe for two time periods (6000 and 0 BP) based on modern and fossil data, notably for climate-biosphere modelling. However, continental-scale descriptions of vegetation types can be less informative about ecologically diverse sub-regions, such as the Mediterranean. There is potential for more detailed classification and reconstruction of Mediterranean ecoregions (e.g. Collins et al., 2012), which can allow exploration of how vegetation types developed in relation to human land modification.

The present vegetation of the Mediterranean region is the product of a distinctive climate and natural environment transformed by human activities over many millennia (Jalut et al., 2009). 
90 Improved understanding of the unique vegetation assemblages that characterise the

91 Mediterranean landscape and how these have changed over millennia has potential value in identifying vegetation types at risk from future land use change. Much of the modern Mediterranean vegetation has been altered by deforestation, over-grazing, erosion and

94 burning (Vogiatzakis et al., 2006). In recent decades these factors have led to a shift from highly heterogeneous landscapes maintained by multiple different land uses, to more homogeneous landscapes, for example, following land abandonment on some European shores of the Mediterranean (Pausas, 1999). Wildfires are also an important feature of Mediterranean ecosystems and their associated disturbance regimes (Rundel et al., 1998). Animal grazing has been a constant disturbance factor throughout the Holocene, and has been important in maintaining open and mosaic landscapes (Blondel, 2006). Plant distribution is also restricted by environmental factors such as species’ climatic tolerances and interspecific interactions (e.g. García-Valdés et al., 2015). Climate is an important driver of vegetation turnover through previous interglacial periods (e.g. Langgut et al., 2011) and some studies employ pollen analysis as a tool to reconstruct past climate (e.g. Mauri et al., 2015). Since the mid-Holocene, the increasing impact of human land use has been demonstrated in numerous studies (e.g Colombaroli \& Tinner, 2013). Consequently, disentangling the impacts of climate and human land use on vegetation shifts can be complex, notably for recent millennia.

The aims of this study are to: 1) develop a data-led method for the classification of vegetation types based on modern and fossil pollen datasets across the Mediterranean region; 2) identify temporal and spatial variations in the abundance of different vegetation types and explore whether stable baseline vegetation communities can be identified in the pollen record; and 3) compare these results with previous studies that have classified and mapped vegetation from 
115 pollen data and modern vegetation associations. These aims will be achieved via use of

116 cluster analysis to derive a numerical classification of vegetation types from pollen taxa

117 associations. This approach has the potential to be applied to multiple sequences covering

118 broad geographic regions and is flexible enough to accommodate additional datasets in the

119 future. Databases of modern pollen samples (Davis et al., 2013) and fossil pollen (e.g. Fyfe et

120 al., 2009) have been used for this macro-ecological study.

121

122

METHODS

123

124 Modern and fossil pollen datasets

125

126

Pollen count data have been obtained from the European Modern Pollen Database (Davis et

127

al., 2013) and the European Pollen Database for fossil records (version: May 2016) (Leydet, 2007-2017). The analyses are based on 1799 modern surface samples and 158 fossil pollen records (cores) from 143 sites (Supplementary Information 1). Only pollen sequences with reliable chronologies (sensu Giesecke et al. 2013) were used. These provide more independent age control for the mapping of vegetation change than has been possible in previous studies. The pollen count data from each site have been summed into 200-year time windows from $11000 \mathrm{BP}$ to present. These allow vegetation changes of sub-millennial

134 duration to be identified, avoid 'smoothing' that might result from using longer time windows

135 (Fyfe et al., 2015) and enable direct temporal comparison among sites. The modern (i.e. surface) pollen and most recent (200 BP - present) fossil samples are separated in the analyses. The majority of the modern pollen samples derive from moss polsters or soils and there is no duplication of core top samples between the modern and fossil datasets. This has resulted in 3852 fossil samples distributed across 55 time windows, and a total of 5641 
140 modern/fossil pollen samples. Pollen sites located in areas with characteristic Mediterranean

141 climate and vegetation have been selected for analysis (Fig. 1), as defined using the

142 vegetation zones illustrated by Izdebski et al. (2015) and Ozenda \& Borela (2000). Pollen

143 sites from the Rhone Valley in southern France were also included in the initial cluster

144 analysis to identify land-cover types at higher elevation, but these sites were subsequently

145 removed for analysis of patterns in the Mediterranean, leading to 105 fossil records and 1610

146 modern samples.

148 The taxonomy of the modern and fossil datasets has been harmonised and simplified using

149 the EPD nomenclature (Leydet, 2007-2017). Different levels of taxonomic resolution were

150 chosen for specific purposes. For example, key indicator species; i.e. taxa that are associated

151 with certain land use types, such as arable weeds, were grouped at the species level (e.g.

152 ribwort plantain (Plantago lanceolata)), whereas other taxa were combined at a higher

153 taxonomic level, such as all evergreen oak species and varieties (e.g. Quercus ilex and

154 Quercus suber). There are challenges for pollen analysts in subdividing the Quercus group

155 based on the morphology of the pollen grains. For example, Quercus cerris/suber types,

156 which represent both evergreen and deciduous types, are often combined by analysts due to

157 difficulties in distinguishing them using a light microscope. Certain assumptions are required

158 when utilising large databases that have been compiled from the work of numerous different

159 analysts, for example, 'Quercus undifferentiated’ could represent evergreen or deciduous

160 Quercus when not identified to species level. Within the dataset presented here, deciduous

161 Quercus appears in 150 sequences and evergreen Quercus has been identified in 125

162 sequences, therefore in the majority of cases analysts have separated different oak types.

163 Only taxa with $>1 \%$ occurrence that occur in $>50$ samples were included, resulting in 260

164 pollen taxa. The geographical coverage of this dataset is good for most of the European 
165 Mediterranean but poorer for the African side. This needs to be taken into account when interpreting results, as all phytogeographical conditions may not be represented. The terms

167 'vegetation clusters’ and ‘vegetation/pollen assemblages’ are used interchangeably and

168 'cluster group' is used to describe the resulting collection of pollen samples that fall into a 169 particular ‘cluster’ number.

170

\section{Data analysis}

172

173 Ward's hierarchical agglomerative clustering method (Ward, 1963; Murtagh \& Legendre, 174 2014) has been applied to the amalgamated modern and fossil pollen dataset using the 'Rioja' 175 R package (Juggins, 2015). This unsupervised data-driven approach was used to assign pollen samples to cluster groups based on the similarity of their taxa assemblages without excluding any land pollen taxa from the dataset (other than those $<1 \%$ with fewer than 50 occurrences). Whilst many approaches exist for classification of multivariate data, these generally produce

179 similar results in pollen datasets (Felde et al., 2014; Felde et al., 2016). Cluster analysis 180 allows hierarchical aggregation at different classification levels (García-Madrid et al., 2014). Detailed comparison of the pollen samples and assemblages at different clustering levels has allowed exploration of the cluster groups that separate at a lower clustering level (e.g. six clusters) and are represented by more distinct vegetation groups (Table 1). Unsupervised

184 cluster analysis assigns pollen samples into a predetermined number of groups. The ratio of change between cluster groups through time, which may represent a measure of community turnover, was calculated by identifying the number of pollen samples that switch to a new cluster or remain within the same cluster between successive time windows and transforming these values into a ratio of change to non-change. 
190 After assigning pollen samples to clusters statistically, a phytosociological classification

191 approach was used to identify the frequent and abundant taxa within each group based on the number of occurrences of the taxon, the average percentage, median and interquartile range

193 (IQR). The resulting community tables were used to facilitate the selection of interpretive

194 name descriptors for each cluster based on the most frequent/abundant taxa along with 195 comparisons with other classification systems (Küchler \& Zonneveld, 1998; Bossard et al., 2000; Allen, 2009). The pollen cluster groups have also been compared against land cover and land use types defined by the Corine (COoRdination of INformation on the Environment) remotely-sensed land cover maps (European Environment Agency (EEA), 2016) and the results of previous studies (Huntley, 1990; Prentice et al., 1996; Guliot et al., 1996; Peyron et al., 1998). An individual taxon's frequency is determined by calculating its number of occurrences divided by the number of samples in the cluster and assigning one of five frequency classes based on cut-off values between each group, which follows the method used by Perez et al. (2015). If a taxon appears in $81-100 \%$ of all samples in the cluster group it is assigned the highest frequency class. The relative proportions of samples in each cluster group have been calculated for each fossil pollen 200-year time window and the modern pollen surface samples.

207

Non-metric multidimensional scaling (nMDS) was applied to the data using the R 'vegan' package (Oksanen et al., 2016) as a complementary method to summarise major variation in the dataset. Kernel density plots of nMDS scores have been produced to show the overlap or distinctiveness of cluster groups in ordination space with contours to highlight greater density of samples. Simpson's diversity index has been calculated for each pollen sample using raw pollen percentage data. This diversity index was selected as it takes both species richness and

214 evenness into account (Simpson, 1949) and is frequently used to explore diversity change in 
215 pollen datasets (e.g. Morris et al., 2014). Although species diversity indices provide only

216 limited information about community ecology and species abundance (Chiarucci et al., 2011)

217 this index provides a complementary method and has allowed diversity change in the pollen

218 datasets to be explored independently of the cluster analysis approach. The differential pollen

219 productivity of different plant types is not accounted for in the methods presented here;

220 therefore, some high pollen producers, such as Pinus, may be over-represented in some

221 clusters. Lower pollen producers are recognised within the method, as they may appear consistently represented in certain clusters as frequent taxa in spite of their lower abundance values.

\section{RESULTS}

\section{Defining pollen cluster groups}

After analysing the community classification of various groups of sites at different hierarchical levels (Table 1) within the dendrogram, 16 clusters have been chosen as a suitable number to reflect the range of land cover types represented in the pollen dataset eight major groups. Preston et al. (2013) suggested that decisions about the number of clusters should be "based on the purpose of the study because there is no single 'correct' classification”. Choosing 16 clusters allows us to address the aims of this study and identify changes in key vegetation assemblages through time. Some of the open land cover clusters are composed of complex mixtures of relatively low abundance, but frequently occurring taxa, whereas forest (closed vegetation) clusters are usually distinguished by one or two dominant arboreal taxa (Fig. 2). The open vegetation clusters include both 'anthromes' 
240 (anthropogenic biomes; Ellis, 2015), such as grassland, with indicators of arable and

241 disturbed land, and naturally occurring open land cover types, such as steppe. Some clusters

242 were composed entirely of either fossil or modern samples, i.e. indicating the possible

243 existence of non-analogue vegetation assemblages. Clusters are presented according to their

244 corresponding 'super group', i.e. a broader group that they are statistically assigned to at a

245 lower clustering level (Table 1). Many of the pollen records do not cover the entire Holocene;

246 therefore some periods of time are represented by fewer sites than others. The number of sites

247 does not drop below 30 for any time interval, which is a suitable number for calculating

248 averages. However, site numbers do drop below 30 when split by elevation group, and

249 interpretations need to be made with caution when site numbers are very low for a particular

250 time window.

251

252 Some cluster groups comprise pollen samples that are similar to one another while other

253 cluster groups are more diverse when mapped by nMDS scores (Fig. 3). For example, all of

254 the open vegetation clusters occupy a larger area in nMDS space while the forested clusters

255 occupy smaller areas on the plots. The nMDS stress value was 0.224 , which indicates that the

256 analysis cannot adequately collapse the variability within the 260 taxa across the samples into

257 two dimensions. This explains the overlap of clusters within the nMDS ordination space and

258 highlights the value of the cluster analysis approach in providing a more detailed and useful

259 way to identify major vegetation types.

260

261

Defining Mediterranean vegetation types

262

263

Open vegetation assemblages 
264 The pollen taxa assemblages derived for clusters 1.1 (sclerophyllous parkland), 1.2

265 (evergreen oak shrubland: Oleaceae), 1.3 (sclerophyllous steppe/parkland) and 1.4

266 (parkland/grassland) are typical of open landscapes, which are often recognised as being

267 human modified (Table 1; see Fyfe et al., 2018). Cluster 1.1 is a very mixed group with

268 median values below $8 \%$ for all frequently-occurring taxa, while cluster 1.2 has high values

269 for Oleaceae, which includes both cultivated olive groves and wild trees. The most frequent

270 and abundant taxon in cluster 1.3 is goosefoot family (Chenopodiaceae), a typical steppe-land

271 type, but this cluster also includes frequent occurrence and relatively high abundance of pine

272 (Pinaceae), grass (Poaceae) and mugwort/wormwood (Artemisia). Cluster 1.4

273 (parkland/grassland) is a very large group that includes 583 pollen samples. The cluster

274 includes high values for grass, with frequent occurrence of pine, deciduous/evergreen oak

275 (Quercus), arable and grassland indicators. Many of these taxa have broad IQR values

276 indicating a mixed and varied group. Within cluster 2.0 (evergreen shrubland/woodland:

277 Quercus), certain taxa have higher IQR than others, for example, evergreen oak has a fairly

278 narrow IQR, while grass in contrast has a large IQR, indicating that evergreen oak is the

279 distinctive taxon for this cluster.

280

281 The removal of aquatic pollen taxa and spores (such as Myriophyllum, Menyanthes,

Sphagnum, Potamogeton) from the dataset means that identifying wetlands is restricted.

283 However, sedges (Cyperaceae) include both aquatic and dryland plants, so this taxon has

284 been included in the dataset. Cluster 3.0 (pasture/wetland) is distinguished by high values of sedge and also includes frequent occurrence of pine and grass. It is common at sites above 500 masl, where it appears to represent pastureland, as well as some lowland sites where it is more likely to be indicative of wetlands. 
289

290

291

292

293

294

295

296

297

298

299

300

301

302

303

304

305

306

307

308

309

310

311

312

313
Pine forests/woodlands

Clusters 4.0 (pine forest), 5.1 (pine woods), 5.2 (pine steppe) and 7.0 (fir forest) are dominated by pine (Table 1), which produces high amounts of pollen that can travel great distances (Broström et al., 2008) and can be over-represented in pollen records. There are many Mediterranean pine species with contrasting ecologies, ranging from Pinus sylvestris, which is typical of cooler montane environments, to Pinus halepensis that grows in coastal regions. These different species of pine may not always be consistently or easily distinguished palynologically, and this limits the environmental significance of the combined Pinus clusters; however, the associated taxa (the constant, frequent and common types) can assist in understanding the nature of the vegetation communities represented in these samples. Cluster 5.2 (pine steppe) is dominated by a combination of pine, grass and sedge with similar values for each, whereas cluster 7.0 is a distinctive fir cluster group, which also includes a mixture of other deciduous and coniferous woodland types. Abies and Picea have been separated from Pinus in the dataset and Pinaceae is mainly composed of Pinus, but as other genera such as Cedrus are in the same family, the name used here to describe this group is Pinaceae.

\section{Deciduous and mixed forests/woodlands}

This "super group" includes clusters 6.1 (deciduous oak woods), 6.2 (deciduous oak parkland), 8.1 (alder woods), 8.2 (coniferous forest), 8.3 (beech woods) and 8.4 (mesic forest) (see Table 1 for a list of the dominant taxa in these groups). Cluster 6.1 is a distinct deciduous oak class whereas grass and pine are also key taxa in cluster 6.2. Cluster 8.1 includes samples with a high, but wide, IQR for alder, with frequent but lower values of a selection of other deciduous woodland types, pine, sedge and grass. Cluster 8.3 has high average values for beech (Fagus) and other taxa that occur frequently in the dataset, and cluster 8.2 represents a 
combination of spruce, pine and fir. Cluster 8.4 is distinct from the other clusters in this broad

315

316

317

318

319

320

321

322

323

324

325

326

327

328

329

330

331

332 group and described as 'mesic forest' with high average values for elm, hazel and oak, although, pine, grass, birch, alder and sedge also frequently occur in samples in this group and all taxa have fairly wide IQR, indicating that this is a varied woodland group.

\section{Deciphering patterns of vegetation change}

The overall patterns of Holocene vegetation change (Fig. 4) reveal that pine forest (4.0), pine woods (5.1) and deciduous oak woods (6.1) dominated the early Holocene period prior to 8000 BP. These were then partly replaced by other cluster groups, especially wooded parkland (e.g. cluster 6.2: deciduous oak parkland and 1.1: sclerophyllous parkland) into the mid-Holocene (i.e. 8000-4500 BP). Some vegetation clusters increased in abundance during the latter part of the record after 4500 BP (e.g. 3.0 (pasture/wetland) and 1.4

(parkland/grassland). A number of clusters also only appear in the second half of the Holocene, such as 8.3 (beech woods), 8.1 (alder woods) and 1.2 (evergreen shrubland: Oleaceae). The declining nMDS scores and varied ratio of change in the early Holocene appears to reflect shifts in vegetation patterns as a result of natural processes, notably adaptation to the onset of interglacial climatic conditions. This was followed a period of greater vegetation stability between $\sim 9000$ and 6000 BP with more consistent nMDS scores and steadily increasing diversity. Since the mid to late Holocene there has been an increasing ratio of change in the pollen-inferred vegetation clusters (since 5000 BP) and nMDS scores (since 2000 BP), while the Simpson's diversity index steadily increased throughout the entire Holocene. The nMDS patterns (Fig. 3) indicate that the open vegetation types that have prevailed during the later Holocene are more diverse taxonomically. Overall, the ratio of change and analysis of ecosystem trajectories (Fyfe et al., 2018) indicate continual turnover 
339 during the Holocene, rather than any clearly identifiable stable baseline state for

340 Mediterranean vegetation.

341

342 Grouping sites according to elevation has revealed that needle-leaf forests (4.0, 5.1 and 5.2)

343 and deciduous oak woods/parkland (6.1 and 6.2) were abundant in the early Holocene at the

344 lowest elevation (below 500 m) (Fig. 5). Parkland/grassland (1.4), sclerophyllous

345 steppe/parkland (1.3) and pasture/wetland (3.0) then become more abundant from the mid-

346 Holocene, and in the most recent 5000 years evergreen shrubland (Oleaceae) (1.2) and alder

347 woods (8.1) increase. Evergreen shrubland (1.2) is most abundant in this lowest elevation

348 group. At mid-elevation levels (between 500-1200 m) in addition to pine forest types, mesic

349 forest (8.4) has high values in the early Holocene, while beech woods (8.3) become

350 significant after $\sim 3500$ BP. Conifer trees are most common at the highest elevation level

351 (above $1200 \mathrm{~m}$ ), with pine forest/woods types (4, 5.1 and 5.2) having very high values in the

352 early Holocene (greater than $80 \%$ when pine clusters are combined), which are then partly

353 replaced by fir, conifer and pine steppe (7.0, 8.2 and 5.2).

354

355 There are cluster groups in the fossil record that are not represented in the modern dataset; for

356 example, mesic forest (8.4), which may represent a non-analogue community, as it is also

357 absent in the most recent fossil pollen time window (200 BP - present). However, there are no

358 groups that are present in the modern dataset that are not also present in the fossil dataset,

359 although some clusters appear rarely, for example, 2.0 (evergreen shrubland: Quercus) and

3601.2 (evergreen shrubland: Oleaceae). The modern surface samples cover a much larger

361 geographical area, as there are around ten times more site locations than in the fossil dataset,

362 and greater diversity of landscape types may be therefore expected in the modern dataset. On 
363

364

365

366

367

368

369

370

371

372

373

374

375

376

377

378

379

380

381

382

383

384

385

386

387

the other hand, the fossil dataset is much larger than the surface pollen dataset in terms of the number of samples included and encompasses landscape types that have changed over time.

\section{DISCUSSION}

The pollen-based results indicate that modern/recent vegetation in the Mediterranean basin is spatially diverse, in accord with vegetation mapping using remote sensing and ground-level field survey, as reflected by the Corine remote sensed land cover map (Fig. 6). The similarity between pollen clusters and the Corine maps is best in areas with homogeneous land cover, whereas more heterogeneous landscapes lead to poorer matches (Woodbridge et al., 2014). The Corine map and pollen-inferred vegetation clusters show good overall similarities, for example, parkland/grassland (1.4) and sclerophyllous parkland (1.1) are similarly reflected by both datasets in north central Spain while the evergreen shrubland (Oleaceae) (1.2) cluster is located in areas of olive groves in south central Spain shown on Corine maps. However, there are also dissimilarities, which relate to the difference in these two data types in sensing vegetation patterns (Woodbridge et al., 2014). This partly results from the amalgamation of pollen types reaching a site in a mosaic landscape and the difficulty in identifying some landscape types palynologically. Differential pollen productivity and dispersal may lead to over-representation of pine forests and under-representation of some herbaceous taxa and thus open vegetation types.

Plotting pollen samples in nMDS space according to cluster group (Fig. 3) provides an independent assessment of the major patterns within the dataset, although the full range of variability is not captured by two dimensions. Similar vegetation types identified according to the cluster analysis approach occupy similar areas of nMDS ordination space, such as all pine 
dominated forest types (4.0, 5.1 and 5.2) while the two evergreen shrubland types (1.2 and 2.0) also occupy similar nMDS space.

\section{Temporal dynamics in vegetation patterns}

The cluster analysis-based approach and datasets presented here and in a companion paper (Fyfe et al., 2018) focussing on exploring trajectories of change, permit a more detailed description of Mediterranean vegetation change through the Holocene than some previous studies. Prentice et al. (1996), for example, identified only four key vegetation types in the Mediterranean: xerophytic woods/scrub, temperate deciduous forest, broad-leaved evergreen/warm mixed forest, and steppe. These vegetation types are reflected by the limited array of pollen clusters shown in Fig. 6. Within the 'BIOME 6000' mapping project (Prentice et al., 1996), the Mediterranean was dominated by “temperate deciduous broad-leaf forest” at 6000 BP and by “xerophytic woods/scrub” and "warm-temperate evergreen broad-leaf and mixed forest” at $0 \mathrm{BP}$. The vegetation clusters presented in our new analysis reveal a much wider range of forest types, which appear to shift northwards between $6000 \mathrm{BP}$ and the present day. For example, they include 6.2 (deciduous oak parkland), 4.0 (pine forest) and 5.1 (pine woods) in northern Spain at 6000 BP, while 1.1 and 1.3 (sclerophyllous clusters) were restricted to southern Spain. The forest types in northern Spain were then replaced by clusters 1.1 and 1.3 and other open vegetation types (e.g. 1.4 (parkland/grassland) and 3.0 (pasture/wetland) while some forests persisted, primarily in upland regions, with the appearance of others such as 8.3 (beech woods). This matches the BIOME 6000 analysis of vegetation change in Iberia and Greece between the mid-Holocene and modern presented in Roberts et al (2004; plate 7). 
413 In a cluster analysis-based approach, Huntley (1990) identified key taxa associations using

414 percentage data for 44 pollen taxa, which were placed on a six-point smoothed scale, and 415 mapped these across Europe for specific time slices. According to Huntley (1990), at 6000 416 BP the Mediterranean was represented by three vegetation types (described in Table 2). The 417 pollen cluster results presented for the current study provide a more detailed reconstruction of 418 vegetation assemblages and greater representation of open landscapes (Fig. 6). For example, 419 cluster 1.4 (parkland/grassland) and 1.1 (sclerophyllous parkland) are the main open landscapes in Italy, while 1.3 (sclerophyllous steppe/parkland) and 1.2 (evergreen shrubland: Oleaceae) are more widely represented in Spain.

Differences between the cluster results for the modern and most recent fossil datasets (Fig. 4) may be partly influenced by differences in the spatial distribution of sites. Coniferous, fir and alder woods (clusters 8.2, 7.0 and 8.1) are poorly represented in the surface pollen dataset, but are present in the fossil data, including the most recent time window (200 BP - present).

427 The modern samples are not always co-located with the fossil datasets and thus sample 428 different parts of the landscape. Differences between modern and most recent fossil pollen 429 vegetation types are also due to real changes in land cover that have occurred in recent decades, and are linked to both direct and indirect anthropogenic intervention. This has been demonstrated by Colombaroli et al. (2007) with the disappearance of Abies alba at low 432 altitudes in the Mediterranean since the Neolithic. It is clearly reflected in the cluster results 433 (Fig. 5) when sites are separated by elevation groups, as fir forest (7.0) is well represented above $500 \mathrm{~m}$, but does not appear in the dataset below this altitude.

436 Various factors lead to the existence of non-analogue vegetation assemblages (Williams \& 437 Jackson, 2007), such as rates of postglacial migration (Médail \& Diadema, 2009), climate 
change, human disturbance (Jalut et al., 2009) and altitudinal changes; for example, Geri et al. (2010) found that loss of Mediterranean forest has mostly been confined to low altitude areas. The altitudinal differences in the dataset reflect the ecotone boundaries of vegetation types and land use differences. For example, the only open vegetation type present $>1200 \mathrm{~m}$ is 1.4 (parkland/grassland) and the only forest types represented at low elevation are 6.1 and 6.2 (deciduous oak parkland/woods). In a comparison of Holocene vegetation diversity across a transect from central Europe to the Mediterranean, Colombaroli \& Tinner (2013) identified how diverse open-land ecosystems increase when human disturbance intensifies while forest becomes less diverse, highlighting the important role of anthropogenic fire and other disturbance related activities. Pollen taxa diversity appears to increase with the development of cultural landscapes and not just as a by-product of deforestation (Colombaroli \& Tinner, 2013).

The patterns of change in different plant species and communities may sometimes be missed in the broad scale synthesis presented here. For example, evergreen Quercus ilex communities, which are recognised as more fire resistant than broad-leaf oak forests, developed before the emergence of Neolithic farming and were heavily impacted by land use strategies (e.g. Calò et al., 2012), but this pattern is not clearly shown in the changing abundance of the evergreen shrubland (dominated by Quercus) cluster (2.0). This suggests that regional patterns may become hidden within the broad scale synthesis, and that smaller spatial scale analyses would be required to investigate sub-regional patterns of vegetation change in more detail.

\section{Potential and actual natural vegetation}


463 There has been recent debate about potential natural vegetation (PNV) and the disconnect

464 between PNV, actual vegetation and the role that palaeoecological evidence of past

465 vegetation might play in determining or assessing PNV (e.g. Carrión \& Fernandez, 2009;

466 Chiarucci et al., 2010; Loidi et al., 2010; Jackson, 2013). Jackson (2013) sees PNV as a

467 'useful fiction', but one that might be better informed through use of data such as those

468 presented here, which can be used to develop understanding of the processes that controlled

469 historical vegetation character and change. PNV, when applied to the Iberian Peninsula, has

470 modelled vegetation with a single dominant tree taxon at broad spatial scales (Carrión \&

471 Fernandez, 2009). This is not the case for the clusters generated in this analysis, which

472 indicates frequent co-dominant species, even taking into account differential pollen

473 productivity between taxa (Broström et al., 2008). Whilst it is recognised that the PNV

474 concept encapsulates vegetation that would develop in the absence (or cessation of) human

475 activity (Loidi et al., 2010), it is clear from palynological records that vegetation turnover

476 rather than stability has been the norm in the Mediterranean, even in the absence of human

477 impacts associated with agriculture and pastoralism.

478

479 Several long, continuous pollen records from the Mediterranean (e.g. Sadori et al., 2013)

480 have demonstrated continuous vegetation change during past interglacial periods. These

481 suggest that the character of 'natural' vegetation succession in the Mediterranean has been

482 predictable and comparable during different interglacials (Tzedakis, 2007). Open woodland

483 develops first, followed by expansion of deciduous oak, sclerophyll scrub, elm, hazel and

484 lime, then by fir, beech and spruce, followed by revertance to open woodland. The fact that

485 the early Holocene vegetation clusters presented here show similar patterns implies that

486 predominantly natural processes were driving vegetation succession at least until $~ 8000 \mathrm{BP}$.

487 Magri (1995) suggested that the Holocene interglacial may currently be experiencing a later 
488

489

490

491

492

493

494

495

496

497

498

499

500

501

502

503

504

505

506

507

508

509

510

511

512

phase that matches previous interglacials during which natural openings in forests and the development of grasslands produced environments suitable for agriculture and pastoralism in the current interglacial. However, the complexity of land cover types and frequency of vegetation cluster change during the second half of the Holocene is likely to have been amplified by intensifying human impacts, a pattern also identified by Carrión and Fernandez (2009). In the pollen-based synthesis presented here, for example, total non-arboreal pollen across the Mediterranean increased from $\sim 35 \%$ to $\sim 47 \%$ between 3500 BP and recent times (Fig. 4). Looking to the future, dynamic vegetation models driven by future climate change scenarios predict a shift from mesic forest (the current PNV) to more open shrubland and eventually steppe as a result of reduced water availability (Hickler et al., 2012).

Transformation of the vegetation by human agency has already begun this process over the past millennia.

\section{CONCLUSIONS}

We have demonstrated a method that allows exploration of vegetation dynamics in time and space and potentially the detection of non-analogue communities. A high degree of spatiotemporal heterogeneity is recognised in Mediterranean vegetation patterns (Shoshany, 2000) and this is evident within the results presented here. In comparison with some previous classification studies, such as the BIOME mapping vegetation classification (Prentice et al., 1996; Roberts et al., 2004), which often focussed on discrete time windows, our results show almost continuous turnover of most plant communities during the last 11,000 years, as demonstrated by the rate of vegetation cluster change (Fig. 4). This indicates that stable baseline vegetation communities cannot be easily identified, at least not at a panMediterranean scale. Our transformation and synthesis of multiple modern and fossil pollen 
513 records has revealed key vegetation types that existed in the past and are rare or absent in the

514 modern landscape (e.g. mesic forest) and vice versa (e.g. evergreen shrub dominated by

515 Oleaceae). The pollen cluster results highlight the potential of this approach to explore

516 complex vegetation patterns and provide detailed information about vegetation assemblages

517 not previously identified, which is open to future development with the availability of

518 additional datasets.

519

520 While it can be difficult to establish precise causes for changes in vegetation, stochastic

521 characteristics, associated with a range of disturbance factors, such as natural fire, climate

522 fluctuations and human impacts, will have resulted in what are often considered to represent

523 'subclimax' vegetation communities. There is long-standing evidence of the complex

524 interaction between plant assemblages, disturbance and climate (Colombaroli et al., 2007;

525 Guiot \& Kaniewski). If stable natural vegetation communities never existed when viewed on

526 a Holocene timescale, then attempts to use them as targets for environmental restoration may

527 be misplaced. Understanding land cover types in an area of the world with a long-standing

528 (multi-millennial) history of human transformation has potential value in informing

529 palaeoecologists, conservationists, and climate modellers, among other groups concerned

530 with vegetation change and has potential to help identify biogeographic regions that are more

531 resilient or susceptible to future disturbance.

532

533 ACKNOWLEDGEMENTS

534

535 This research is funded by Leverhulme Trust (grant number: RPG-2015-031). The authors

536 would like to thank contributors to the European Pollen Database for sharing their data,

537 Shaun Lewin for assistance with data extraction, Thomas Giesecke for sharing sediment core 
538 chronologies, and Michelle Leydet (the EPD manager). This paper is a contribution to the 539 Past Global Changes (PAGES) project and its working group LandCover6k. LandCover6k is

540 coordinated by Marie-José Gaillard (Linnaeus University, Kalmar, Sweden). Thanks are also

541 given to the Journal of Biogeography editors and four reviewers for their constructive and

542 helpful comments.

543

544

DATA AVAILABILITY STATEMENT

545

546 The datasets underpinning this study are publically available from the European Pollen

547 Database (http://www.europeanpollendatabase.net/). The results of the analyses carried out

548 are available from the authors upon request.

549

550

REFERENCES

551

552 Allen, H. (2009) Vegetation and Ecosystem Dynamics. In: Woodward, J. (Ed.) The Physical Geography of the Mediterranean. Oxford University Press, New York.

554 Blasi, C., Capotorti, G., Copiz, R., Guida, D., Mollo, B., Smiraglia, D. \& Zavattero, L. (2014)

555 Classification and mapping of the ecoregions of Italy. Plant Biosystems, 148, 1255-

556 1345.

557

Blondel, J. (2006) The ‘Design’ of Mediterranean Landscapes: A Millennial Story of Humans

558 and Ecological Systems during the Historic Period. Human Ecology: An

559 Interdisciplinary Journal, 34, 713-729.

560

Bossard, M., Feranec, J. \& Otahel, J. (2000) Corine land cover technical guide: addendum 2000. Technical report 40. European Environment Agency, Copenhagen. 
562 Brewer, S., Giesecke, T., Davis, B.A.S., Finsinger, W., Wolters, S., Binney, H., de Beaulieu, J-L., Fyfe, R., Gil-Romera, G., Kühl, N., Kuneš, P., Leydet, M. \& Bradshaw, R.H. (2017) Late-glacial and Holocene European pollen data. Journal of Maps, 13, 921928.

Broström, A., Nielsen, A.B., Gaillard, M.J., Hjelle, K., Mazier, F., Binney, H., Bunting, M.J., 567 Fyfe, R.M., Meltsov, V., Poska, A., Räsänen, S., Soepboer, W., Stedingk, H., Suutari, H. \& Sugita, S. (2008) Pollen productivity estimates: the key to landscape reconstructions. Vegetation History and Archaeobotany, 17, 461-478.

Calò, C., Henne, P.D., Curry, B., Magny, M., Vescovi, E., La Mantia, T., Pasta, S., Vannière, change in southern Sicily. Palaeogeography, Palaeoclimatology, Palaeoecology, 323325, 110-122.

Carrión, J.S. \& Fernández, S. (2009) The survival of the ‘natural potential vegetation’ concept (or the power of tradition). Journal of Biogeography, 36, 2202-2203.

Chiarucci, A., Bacaro, G. \& Scheiner, S.M. (2011) Old and new challenges in using species diversity for assessing biodiversity. Phil. Trans. R. Soc. B, 366, 2426-2437.

Chiarucci, A., Araújo, M.B., Decocq, G., Beierkuhnlein, C. \& Fernández-Palacios, J.M. (2010) The concept of potential natural vegetation: an epitaph? Journal of Vegetation Science, 21, 1172-1178.

Collins, P.M., Davis, B.A.S. \& Kaplan, J.O. (2012) The mid-Holocene vegetation of the Mediterranean region and southern Europe, and comparison with the present day. Journal of Biogeography, 39, 1848-1861.

584 Colombaroli, D \& Tinner, W. (2013) Determining the long-term changes in biodiversity and 585 provisioning services along a transect from Central Europe to the Mediterranean. 
587 Colombaroli, D., Marchetto, A \& Tinner, W. (2007) Long-term interactions between Mediterranean climate, vegetation and fire regime at Lago di Massaciuccoli (Tuscany, 589 Italy). Journal of Ecology, 95, 755-770.

Davis, B.A.S., Zanon, M., Collins, P. et al. (2013) The European modern pollen database (EMPD) project. Vegetation History and Archaeobotany, 22, 521-530.

592 Edwards, K.J., Fyfe, R.M. \& Jackson, S.T. (2017) The first 100 years of pollen analysis. Nature Plants, 3, doi:10.1038/nplants.2017.1

594 595

Ellis, E. (2015) Ecology in an anthropogenic biosphere. Ecological Monographs, 85, 287331.

European Environment Agency (EAA) (2016) Corine Land-cover 2006 raster data. Online: http://www.eea.europa.eu/data-and-maps/data/corine-land-cover-2006-raster-3 Accessed: 6/9/16.

Felde, V.A., Hooghiemstra, H., Torres-Torres, V. \& Birks, H.J.B (2016) Detecting patterns of change in a long pollen-stratigraphical sequence from Funza, Colombia - A comparison of new and traditional numerical approaches. Review of Palaeobotany and Palynology, 234, 94-109.

Felde, V.A., Bjune, A.E., Grytnes, J.A. \& Birks, H.J.B. (2014) A comparison of novel and traditional numerical methods for the analysis of modern pollen assemblages from major vegetation-landform types. Review of Palaeobotany and Palynology, 210, 2236.

Fyfe, R.M., Woodbridge, J. \& Roberts, N. (2018) Trajectories of change in Mediterranean Holocene vegetation through classification of pollen data. Vegetation History and

610 Fyfe, R.M., de Beaulieu, J.L., Binney, H., Bradshaw, R.H., Brewer, S., Le Flao, A., 611 Finsinger, W., Gaillard, M.J., Giesecke, T., Gil-Romera, G. \& Grimm, E.C. (2009) 
612

613

614 García-Madrid, A.S., Molina, J.A. \& Cantó, P. (2014) Classification of habitats highlights

615

616

617

618

619

620

621

622

623

624

625

626

627

628

629

630

631

632

633

634

635

636

The European Pollen Database: past efforts and current activities. Vegetation History and Archaeobotany, 18, 417-424. priorities for conservation policies: The case of Spanish Mediterranean tall humid herb grasslands. Journal for Nature Conservation, 22, 142-156.

García-Valdés, R., Gotelli, N.J., Zavala, M.A., Purves, D.W. \& Araújo, M.B. (2015) Effects of climate, species interactions, and dispersal on decadal colonization and extinction rates of Iberian tree species. Ecological Modelling, 309-310, 118-127.

Geri, F., Amici, V. \& Rocchini, D. (2010) Human activity impact on the heterogeneity of a Mediterranean landscape. Applied Geography, 30, 370-379.

Giesecke, T., Davis, B.A.S., Brewer, S., et al. (2013) Towards mapping the late Quaternary vegetation change of Europe. Vegetation History and Archaeobotany, 23, 75-86.

Guiot, J. \& Kaniewski, D. (2015) The Mediterranean Basin and Southern Europe in a warmer world: what can we learn from the past? Front. Earth Sci., 3, 1-16.

Hickler, T., Vohland, K., Feehan, J., Miller, P. A., Smith, B., Costa, L., Giesecke, T., Fronzek, S., Carter, T.R., Cramer, W., Kühn, I. \& Sykes, M.T. (2012) Projecting the future distribution of European potential natural vegetation zones with a generalized, tree species-based dynamic vegetation model. Global Ecology and Biogeography, 21, 50-63.

Huntley, B. (1990) Dissimilarity Mapping between Fossil and Contemporary Pollen Spectra in Europe for the Past 13,000 Years. Quaternary Research, 33, 360-376.

Izdebski, A., Holmgren, K., Weiberg, E., et al. (2015) Realising consilience: How better communication between archaeologists, historians and natural scientists can transform the study of past climate change in the Mediterranean. Quaternary Science Reviews, 136, 5-22. 
637

638

639

640

641

642

643

644

645

646

647

648

649

650

651

652

653

654

655

656

657

658

659

660

Jalut, G. Dedoubat, J.J., Fontugne, M. \& Otto, T. (2009) A Holocene circum-Mediterranean vegetation changes: Climate forcing and human impact. Quaternary International, 200, 4-18.

Jackson, S.T. \& Blois, J.L. (2014) Community ecology in a changing environment: Perspectives from the Quaternary, 112, 4915-4921.

Jackson, S.T. (2013) Natural, potential and actual vegetation in North America. Journal of Vegetation Science, 24, 772-776.

Juggins, S. (2015) 'Rioja': Analysis of Quaternary Science Data, R package version (0.9-9). (http://cran.r-project.org/package=rioja).

Langgut, D., Almogi-Labin,A., Bar-Matthews, M. \& Weinstein-Evron, M. (2011) Vegetation and climate changes in the South Eastern Mediterranean during the Last GlacialInterglacial cycle (86 ka): new marine pollen record. Quaternary Science Reviews, 30, 3960-3972.

Leydet, M. (2007-2017) The European Pollen Database. (online: http://www.europeanpollendatabase.net/). Accessed: May 2016.

Loidi, J., Del Arco, M., Pérez de Paz, P.L., Asensi, A., Díez Garretas, B., Costa, M., Díaz González, T., Fernández-González, F., Izco, J., Penas, Á. \& Rivas-Martínez, S. (2010) Understanding properly the 'potential natural vegetation 'concept. Journal of Biogeography, 37, 2209-2211.

Magri, D. (1995) Some questions on the late-Holocene vegetation of Europe. The Holocene, 5, 354-360.

Marinova, E., Harrison, S.P. \& Bragg, F. et al. (2017) Pollen-derived biomes in the Eastern Mediterranean-Black Sea-Caspian-Corridor, Journal of Biogeography. 1-16. DOI: 10.1111/jbi.13128. 
661 Mauri, A., Davis, B.A.S., Collins, P.M. \& Kaplan, J.O. (2015) The climate of Europe during

662 the Holocene: a gridded pollen-based reconstruction and its multi-proxy evaluation.

663 Quaternary Science Reviews, 112, 109-127.

664

Médail, F. \& Diadema, K. (2009) Glacial refugia influence plant diversity patterns in the 665 Mediterranean Basin. Journal of Biogeography, 36, 1333-1345.

666

Morris, E.K., Caruso, T., Buscot, F., et al. (2014) Choosing and using diversity indices:

667 insights for ecological applications from the German Biodiversity Exploratories.

668 Ecology and Evolution, 4, 3514-3524.

669

Murtagh, F. \& Legendre, P. (2014). Ward's hierarchical agglomerative clustering method:

670 which algorithms implement Ward’s criterion? Journal of Classification, 31, 274-295.

671

Oksanen, J., Guillaume Blanchet, F., Friendly, M., et al. (2016). ‘vegan’ (Community

672 Ecology Package), R package version 2.4-1. https://CRAN.R-

673 project.org/package=vegan.

674

675

StatSoft Inc. (2003) STATISTICA (data analysis software system), version 6.1. StatSoft, Inc., Tulsa, OK.

Ozenda, P. \& Borela, J.L. (2000) An ecological map of Europe: why and how? Ecology, 323, 677 983-994.

678

Pausas, J.G. (1999) Mediterranean vegetation dynamics: modelling problems and functional

679 types. Plant Ecology, 140, 27-39.

680

Perez, M., Fyfe, R.M., Charman, D.J. \& Gehrels, R. (2015) Later Holocene vegetation

681

682 history of the Isles of Scilly, UK: coastal influence and human land use in a small island context. Journal of Quaternary Science, 30, 764-778.

683

Peyron, O., Guiot, J., Cheddadi, R., Tarasov, P., Reille, M., De Beaulieu, J.L., Bottema, S. \& 684 Andrieu, V. (1998) Climatic reconstruction in Europe for 18,000 year BP. from pollen 685 data. Quaternary Research, 49, 183-196. 
686 Prentice, I.C. \& Webb, T. (1998) BIOME 6000: Reconstructing Global Mid-Holocene

687

688

689

690

691

692

693

694

695

696

697

698

699

700

701

702

703

704

705

706

707

708

709

710 Vegetation Patterns from Palaeoecological Records. Journal of Biogeography, 25, 997-1005.

Prentice, I. C., Guiot, J., Huntley, B., Jolly, D. \& Cheddadi, R. (1996). Reconstructing biomes from palaeoecological data: a general method and its application to European pollen data at 0 and 6 ka. Climate Dynamics, 12, 185-194.

Preston, C.D., Hill, M.O., Harrower, C.A. \& Dines, T.D. (2013) Biogeographical patterns in the British and Irish flora. New Journal of Botany, 3, 96-117.

Roberts, N., Stevenson, A.C., Davis, B., Cheddadi, R., Brewer, S. \& Rosen, A. (2004) Holocene climate, environment and cultural change in the circum-Mediterranean region. In: Past climate variability through Europe and Africa, Battarbee, R.W., Gasse, F. \& Stickley, C. (eds). Kluwer, Dordrecht, pp. 343-362.

Rundel, P.W., Montenegro, G. \& Jaksic, F.M. eds. (1998) Landscape Disturbance and Biodiversity in Mediterranean-Type Ecosystems. Springer, Germany.

Sadori, L., Bertini, A., Combourieu-Nebout, N., Kouli, K., Mariotti Lippi, M., Roberts, N. \& Mercuri, A.M. (2013) Palynology and Mediterranean vegetation history. Flora Mediterranea, 23, 141-156.

Shoshany, M. (2000) Satellite remote sensing of natural Mediterranean vegetation: a review within an ecological context. Progress in Physical Geography, 24, 153-178.

Simpson, E.H. (1949) Measurement of diversity. Nature, 163, 688.

Tzedakis, P.C (2007) Seven ambiguities in the Mediterranean palaeoenvironmental narrative. Quaternary Science Reviews, 26, 2042-2066.

Küchler, A.W. \& Zonneveld, I.S. (1988) The UNESCO Classification of Vegetation. In: Küchler, A.W. \& Zonneveld, I.S. (Eds.) Vegetation mapping. Handbook of vegetation science: vol 10. Springer, Dordrecht. 
711 Vogiatzakis, I.N., Mannion, A.M. \& Griffiths, G.H. (2006) Mediterranean ecosystems: problems and tools for conservation. Progress in Physical Geography, 30, 175-200.

713

Ward, J.H. (1963) Hierarchical grouping to optimize an objective function. Journal of the American Statistical Association, 58, 236-244.

Williams, J.W. \& Jackson, S.T. (2007) Novel climates, no-analogue communities, and ecological surprises. Frontiers in Ecology and the Environment, 5, 475-482.

Woodbridge, J., Fyfe, R.M. \& Roberts, C.N. (2014) A comparison of remotely sensed and pollen-based approaches to mapping Europe’s land cover. Journal of Biogeography. 41, 2080-2092.

\section{BIOSKETCHES}

Jessie Woodbridge is a Post-Doctoral Research Fellow at Plymouth University (UK) and is conducting research that aims to reconstruct changes in European land cover throughout the Holocene using pollen data. Her research background is based on palaeoenvironmental reconstruction, specifically in relation to understanding human impacts and past climate trends.

Ralph Fyfe is Professor of Geospatial Information at Plymouth University. His research focuses on developing innovative methodological approaches to reconstruct patterns of vegetation cover at local to European scales, and deciphering the processes that led to these patterns with an emphasis on human agency.

Neil Roberts is Professor of Geography at Plymouth University. His research emphasises past climatic and environmental change since the last glacial maximum, specifically using lake- 
sediment archives from eastern Africa, the Mediterranean and West Asia. Professor Roberts is a fellow of the Royal Geographical Society, and has served on national and international committees concerning past global changes.

\section{TABLES}

Table 1 Comparison of pollen-inferred vegetation groups within the modern and fossil datasets using Ward's hierarchical clustering method. Towards the left of the table, the groups combine at lower levels of clustering and to the right cluster groups separate as different pollen taxa assemblages are detected at a higher clustering level. The inter-quartile range of the dominant taxa (appearing in $81-100 \%$ of samples in the cluster) are provided.

Table 2 Pollen-inferred vegetation clusters compared with Corine remote sensed land cover maps (EEA, 2016) and vegetation types defined by previous studies (Huntley, 1990; Prentice et al., 1996; Peyron et al., 1998).

\section{FIGURES}

Fig 1 Modern and fossil pollen site locations colour coded according to elevation group. The white area represents the Mediterranean region for which results are presented in this study. Pollen samples in the Rhone Valley of southern France are also shown on the map as these sites contributed to the generation of vegetation cluster groups.

Fig 2 Box plots for pollen taxa within each vegetation cluster group for the combined fossil and modern pollen datasets. The middle vertical bar for each taxon represents the median, the 
761 lower and upper boundaries of the boxes show the interquartile range, and the dashed

762

763

764

765

766

767

768

769

770

771

772

773

774

775

776

777

778

779

780

781

782

783

784

horizontal lines show the minimum and maximum occurrence of the taxon in the cluster. The

bars representing taxa that are frequent or abundant in a specific cluster group are coloured

black and those that are not frequent or abundant are grey (a version of this diagrams has been published in Fyfe et al., 2018).

Fig 3 Modern and fossil pollen samples: non-metric multidimensional scaling (nMDS) kernel density plots for 16 cluster analysis derived vegetation groups. Darker colours indicate greater density of samples and lighter colours indicate fewer samples.

Fig 4 Percentage of pollen samples statistically assigned to each cluster group throughout the Holocene for the entire Mediterranean combined fossil and modern dataset with ratio of vegetation cluster group change, average non-metric multidimensional scaling (nMDS) scores, average Simpson's diversity index and average non-arboreal pollen sum (\% NAP) (scale: 28-48\%) (11,000 BP to modern).

Fig 5 Percentage of pollen samples statistically assigned to each cluster group throughout the Holocene separated by elevation group: a) <500 m (415 modern and 47 fossil pollen sites), b) 500-1200 m (643 modern and 28 fossil pollen sites), and c) >1200 m (498 modern and 30 fossil pollen sites) (11,000 BP to modern).

Fig 6 Pollen-inferred vegetation clusters (6200-6000 BP and modern surface samples) compared with the results of BIOME 6000 vegetation maps (Prentice et al., 1996) for modern pollen (0 BP) and $6000 \mathrm{BP}$ and the Corine remotely-sensed (EEA, 2006) land cover map. 
786 Fig 7 Frequency of vegetation types according to the pollen cluster results and the BIOME

7876000 vegetation maps for 0 BP and 6000 BP maps (Prentice et al., 1996). Similar vegetation

788 types are shown alongside one another.

789

790 Supplementary Information 1: EPD fossil pollen site metadata for the records used in these

791 analyses (for details of the modern pollen sites see Davis et al., 2013).

792

793 Supplementary Information 2: Pollen-inferred vegetation classification tables: land-cover

794 types (clusters) and pollen taxa percentage (inter-quartile range) in the combined modern and

795 fossil pollen datasets (all taxa presented are in the higher frequency class for each cluster)

796 (Lactuceae: synonym Cichorieae). V represents a taxon occurring in $81-100 \%$ of all samples

797 in a cluster and IV $=61-80 \%$. 
Fig. 1

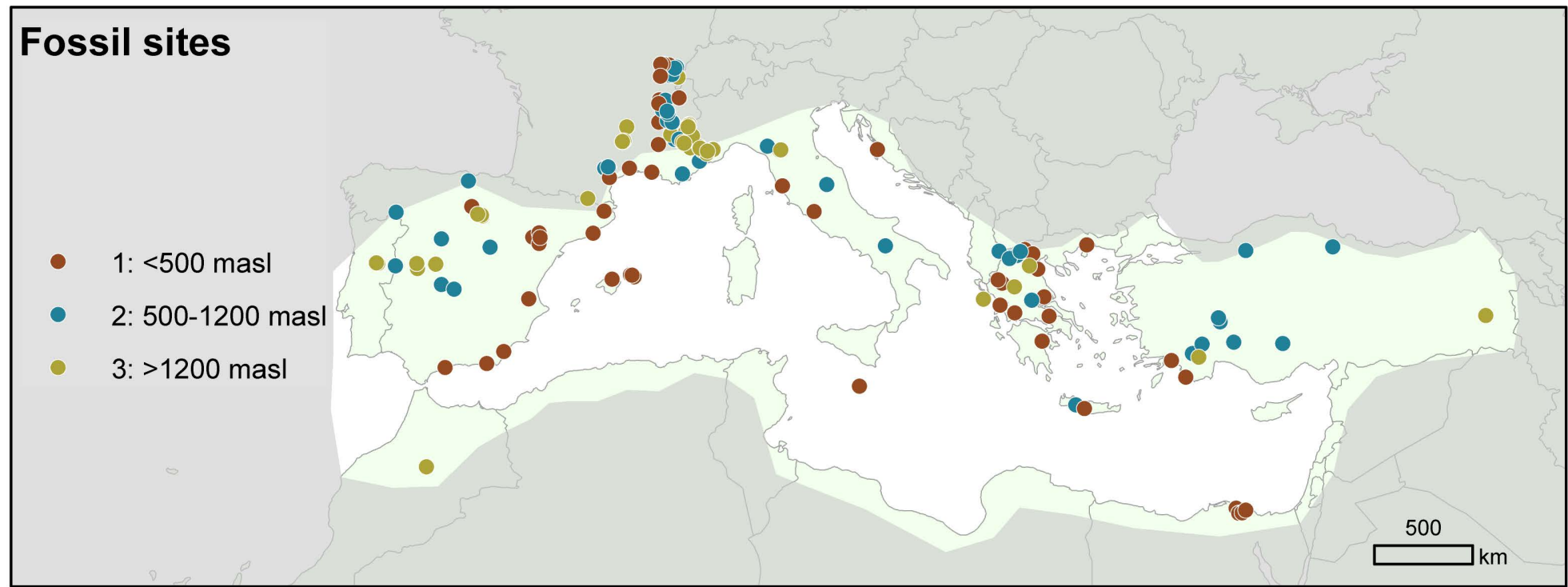

\section{Modern sites}

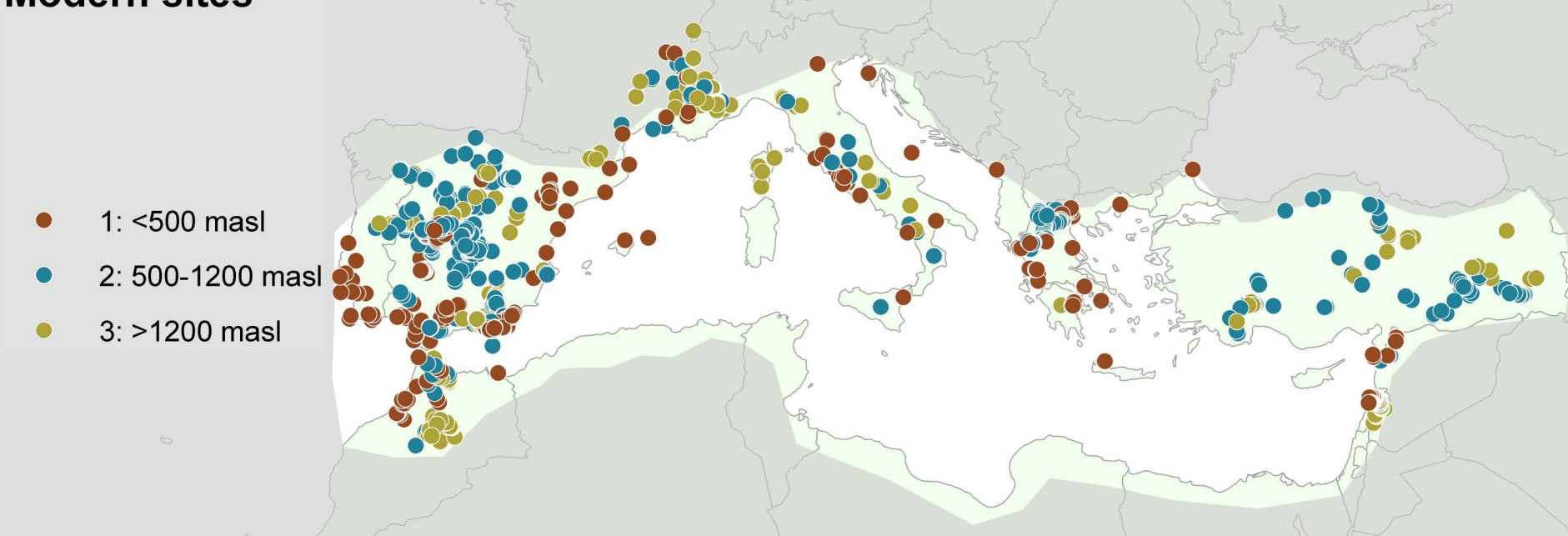


Fig. 2

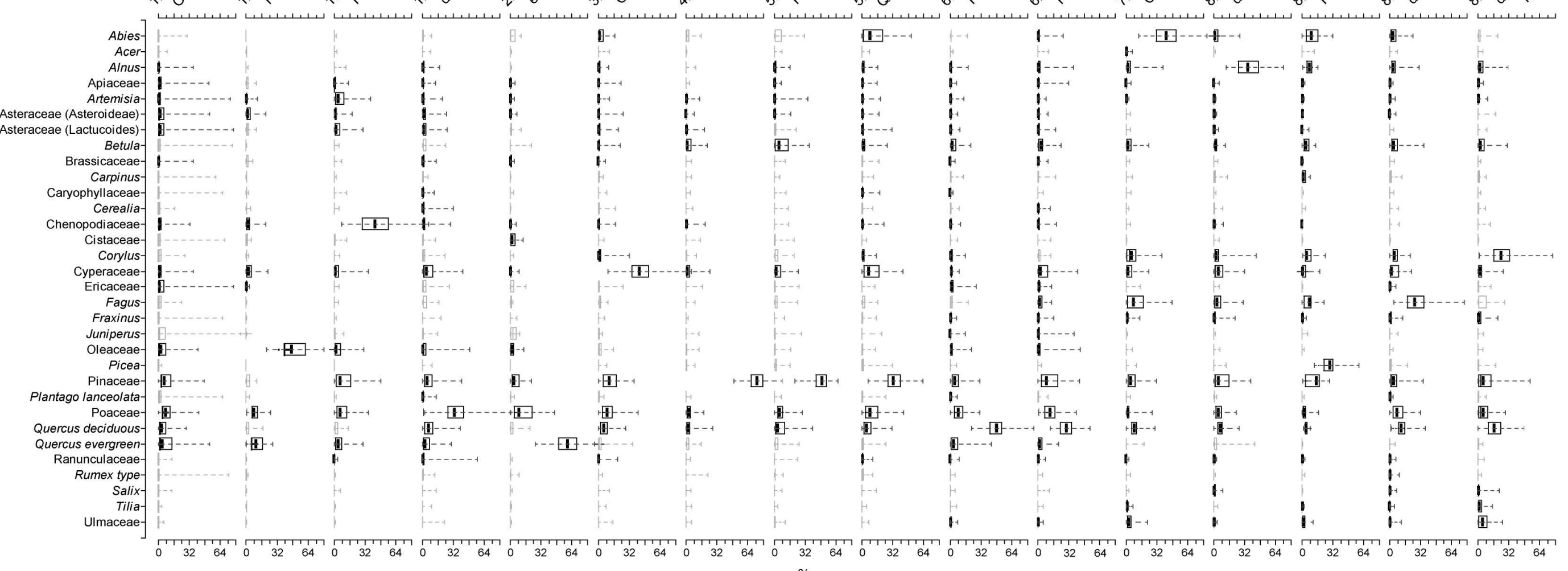



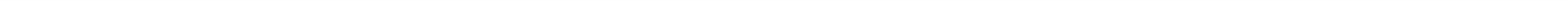
Fig. 4

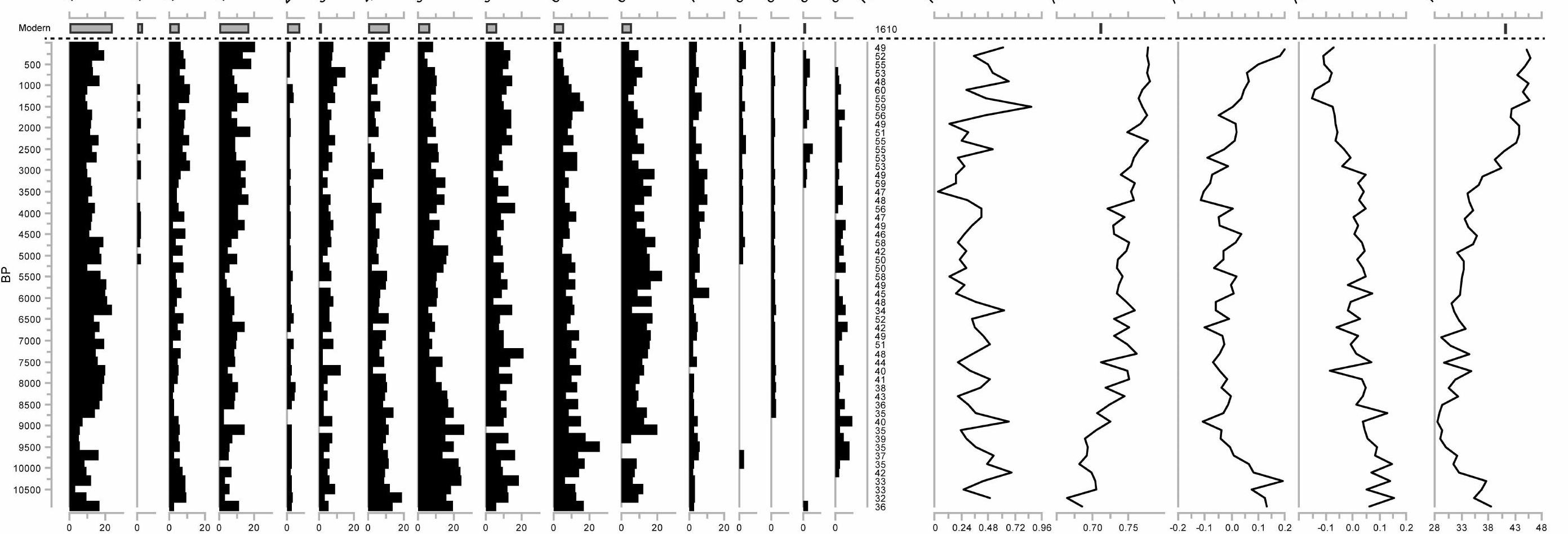


Fig. 6

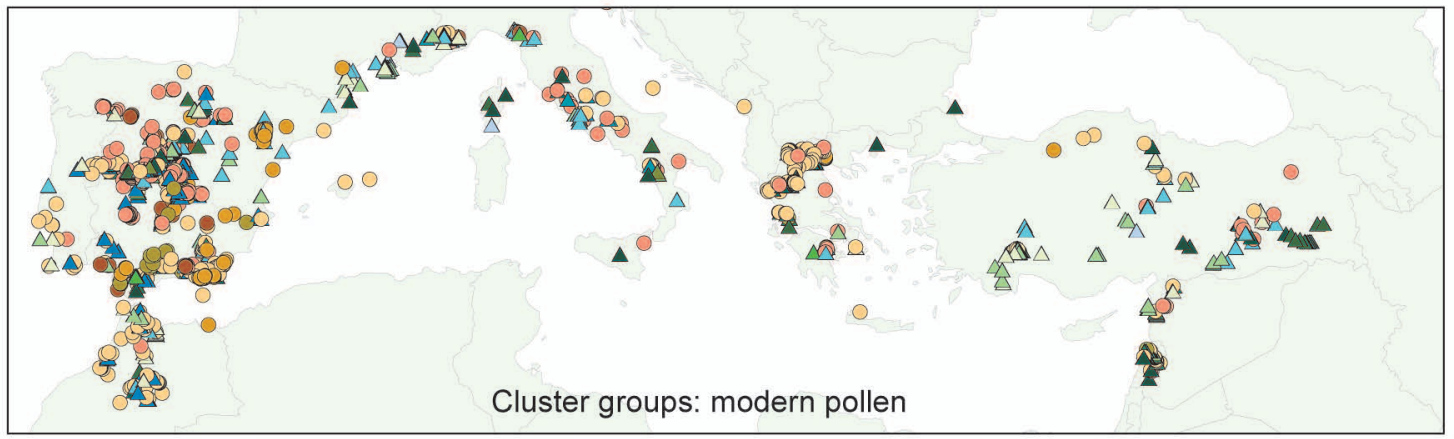

\section{Pollen cluster group}

1.1: Sclerophyllous parkland

- 1.2: Evergreen shrubland (Oleaceae)

- 1.3: Sclerophyllous steppe/parkland

- 1.4: Parkland/grassland

$\triangle$ 2.0: Evergreen shrubland (Quercus)

- 3.0: Pasture/wetland

$\triangle$ 4.0: Pine forest

$\triangle$ 5.1: Pine woods

$\triangle$ 5.2: Pine steppe

$\Delta$ 6.1: Deciduous oak woods

$\Delta$ 6.2: Deciduous oak parkland

$\triangle 7.0$ : Fir forest

$\triangle$ 8.1: Alder woods

$\triangle$ 8.2: Coniferous forest

$\triangle$ 8.3: Beech woods

$\triangle$ 8.4: Mesic forest

$\Delta$

Cluster groups: 6200-6000 BP
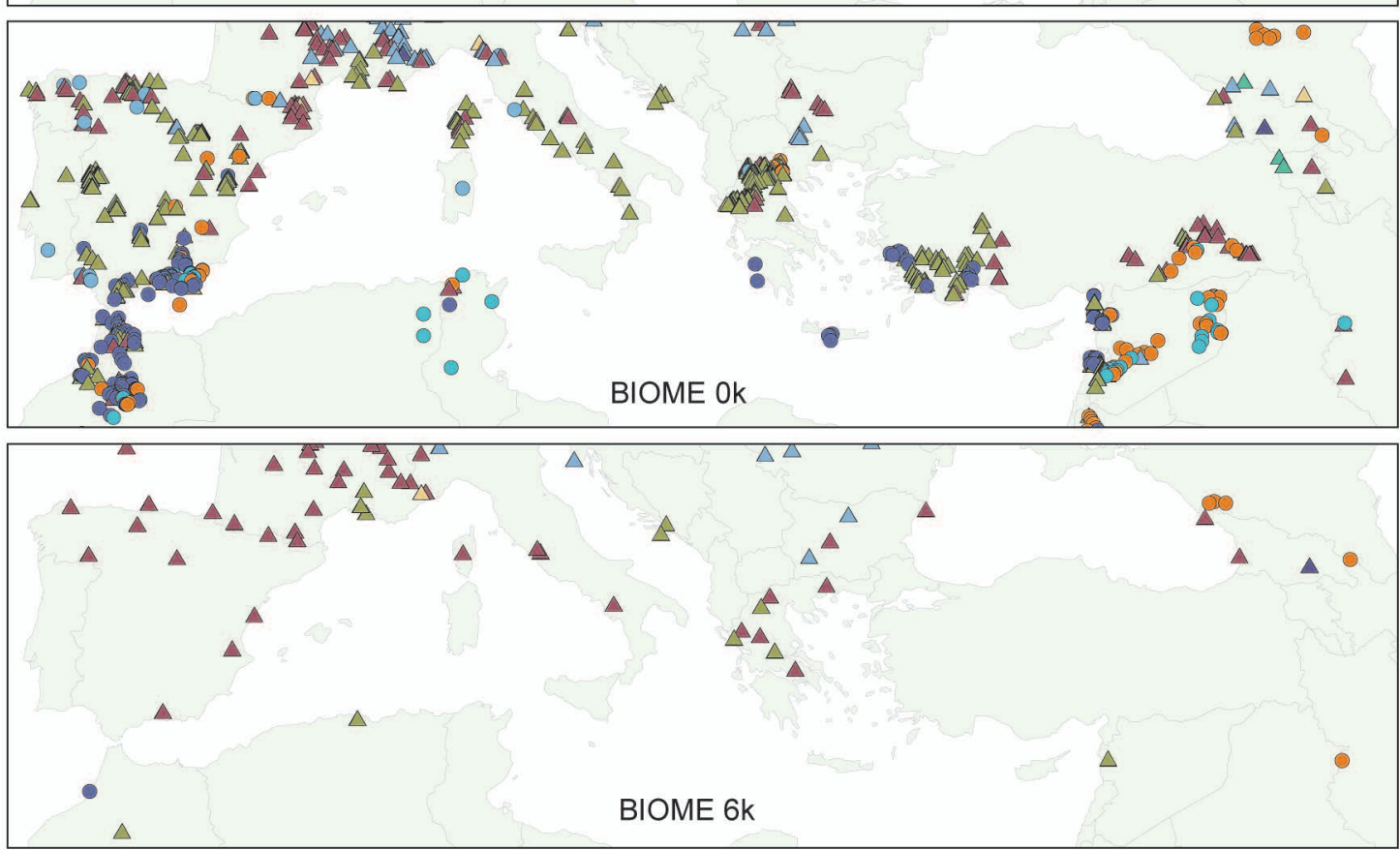

\section{BIOME vegetation types}

- Steppe

- Xerophytic woods/scrub

- Tundra

A Warm-temperate evergreen broadleaf and mixed forest

4 Cool evergreen needleleaf forest

$\triangle$ Cool mixed forest

$\triangle$ Cool-temperate evergreen needleleaf and mixed forest

A Cold evergreen needleleaf forest

A Temperate deciduous broadleaf forest

- Desert

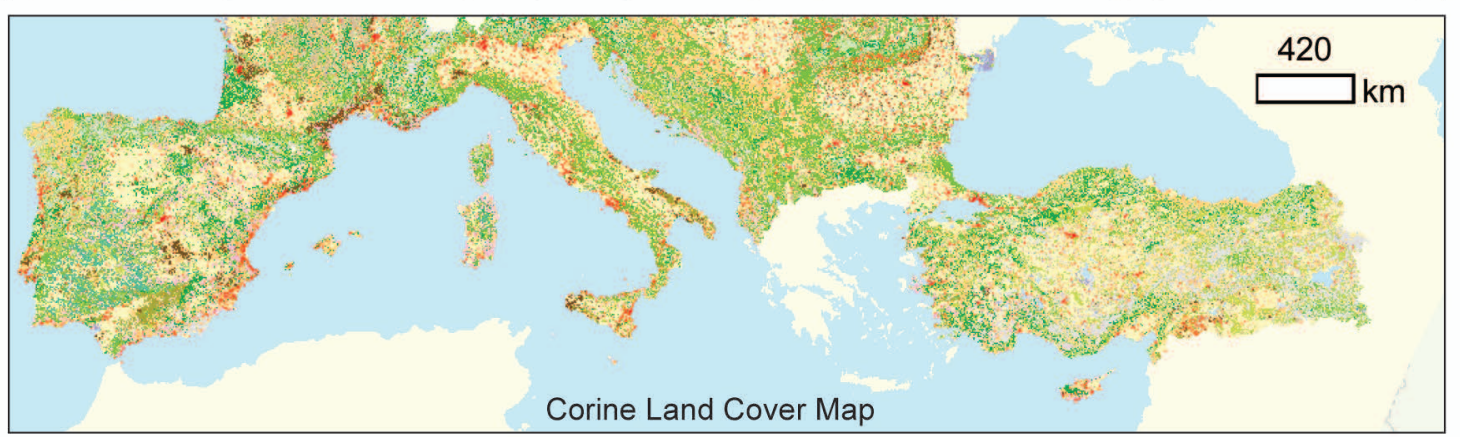

Corine Land Cover Class

\begin{tabular}{l}
\hline Urban fabric \\
\hline Arable land \\
Vineyards \\
Fruit trees and berry plantations \\
$\square$ Olive groves
\end{tabular}

Pastures

Agricultural areas

Agro-forestry areas

Broad-leaved forest

Coniferous forest
Mixed forest

Natural grasslands

Moors and heathland

Sclerophyllous vegetation

Transitional woodland-shrub
Open spaces (little or no vegetation)

Marshes

Peat bogs

Intertidal flats

Water bodies 


\section{Fig. 7}

1.1: Sclerophyllous parkland

1.2: Evergreen shrubland Biome: Xerophytic woods/scrub 1.3: Sclerophyllous steppe/parkland Biome: Steppe

1.4: Parkland/grassland

2.0: Evergreen shrubland Biome: Evergreen broadleaf and mixed forest

3.0: Pasture/wetland

4.0: Pine forest Biome: Cool evergreen needleleaf forest 5.1: Pine woods

5.2: Pine steppe

6.1: Deciduous oak woods Biome: Temperate deciduous broadleaf forest

6.2: Deciduous oak parkland 7.0: Fir forest 8.1: Alderwoods Biome: Cool mixed forest 8.2: Coniferous forest Biome: Evergreen needleleaf and mixed forest

8.3: Beech woods 8.4: Mesic forest

Biome: Tundra

Biome: Desert

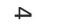

$\sigma$

ウ

-
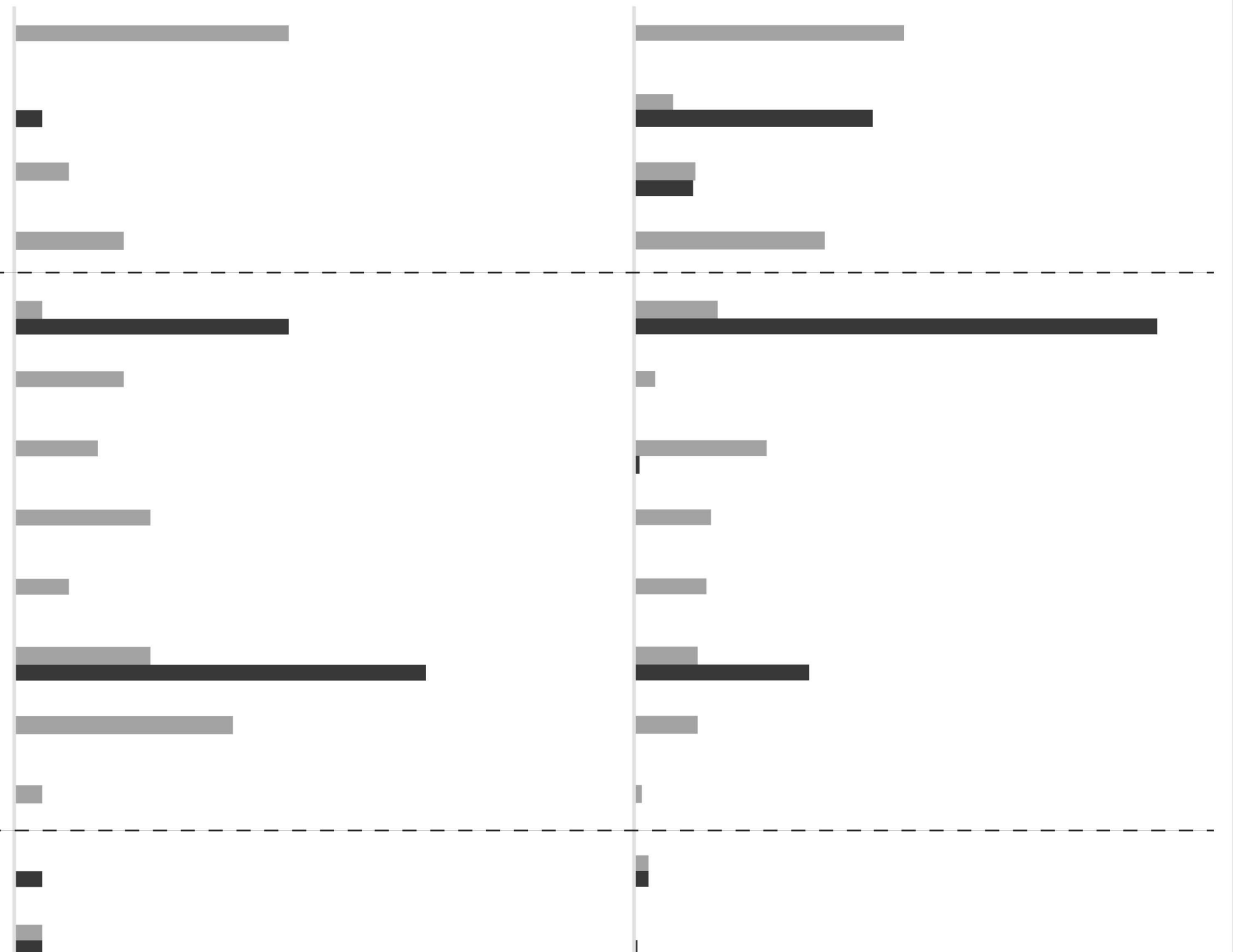
t

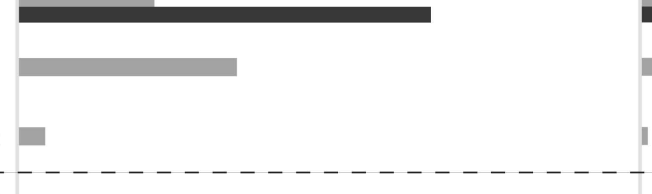


Table 1 Comparison of pollen-inferred vegetation groups within the modern and fossil datasets using Ward's hierarchical clustering method. Towards the left of the table, the groups combine at lower levels of clustering and to the right cluster groups separate as different pollen taxa assemblages are detected at a higher clustering level. The inter-quartile range of the dominant taxa (appearing in 81-100\% of samples in the cluster) are provided.

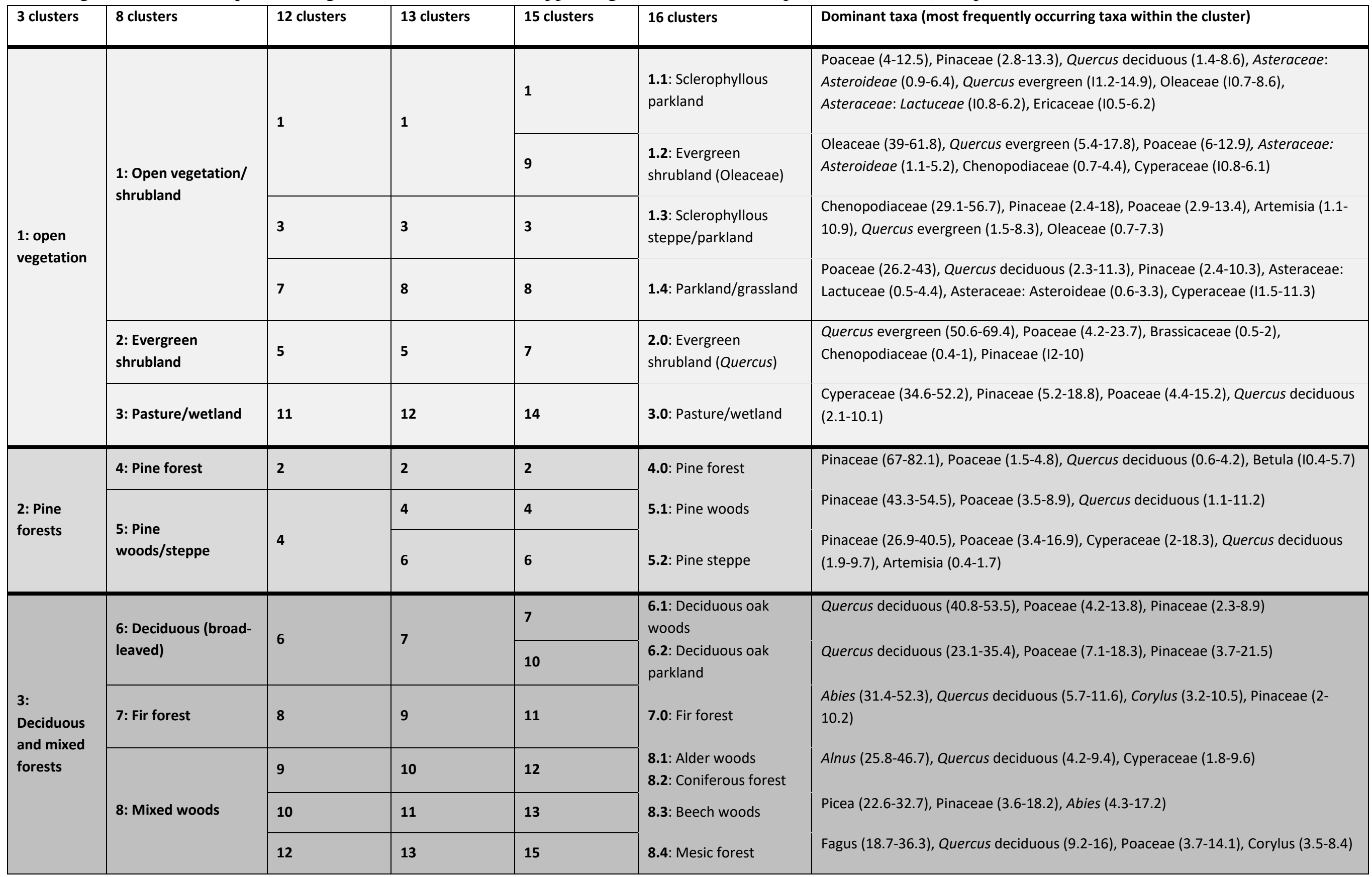



Table 2 Pollen-inferred vegetation clusters compared with Corine remote sensed land cover maps (EEA, 2016) and vegetation types defined by previous studies (Huntley, 1990; Prentice et al., 1996; Peyron et al., 1998).

\begin{tabular}{|c|c|c|c|}
\hline \multirow{2}{*}{ Cluster name descriptor } & \multirow{2}{*}{ Corine Land Cover Classes } & \multicolumn{2}{|c|}{ Comparison with previous studies } \\
\hline & & $\begin{array}{l}\text { Prentice et al. (1996) } \\
\text { Peyron et al. (1998) }\end{array}$ & Huntley (1990) \\
\hline $\begin{array}{l}\text { 1.1: Sclerophyllous parkland } \\
\text { (Poaceae-Quercus-Oleaceae-herbaceous } \\
\text { and sclerophyll taxa) }\end{array}$ & Sclerophyllous vegetation & Grass / heath & $\begin{array}{l}\text { Quercus-Pinus-sclerophyll } \\
\text { taxa } \\
\text { Quercus-Chenopodiaceae- } \\
\text { Pistacia }\end{array}$ \\
\hline $\begin{array}{l}\text { 1.2: Evergreen shrubland } \\
\text { (Oleaceae-Quercus evergreen-Poaceae- } \\
\text { herbaceous and sclerophyllous taxa) }\end{array}$ & $\begin{array}{l}\text { Transitional woodland-shrub / } \\
\text { broad-leaved forest / } \\
\text { sclerophyllous }\end{array}$ & $\begin{array}{l}\text { Warm-temperate sclerophyll } \\
\text { trees/shrub }\end{array}$ & $\begin{array}{l}\text { Quercus-Chenopodiaceae- } \\
\text { Pistacia }\end{array}$ \\
\hline $\begin{array}{l}\text { 1.3: Sclerophyllous steppe/parkland } \\
\text { (Chenopodiaceae-Poaceae-Artemisia- } \\
\text { Quercus evergreen-Oleaceae) }\end{array}$ & Sclerophyllous vegetation & Steppe forb / shrub & $\begin{array}{l}\text { Chenopodiaceae } \\
\text { Quercus-Pinus-Ericales- } \\
\text { Chenopodiaceae }\end{array}$ \\
\hline $\begin{array}{l}\text { 1.4: Parkland/grassland } \\
\text { (Poaceae, Quercus deciduous, } \\
\text { Asteraceae) }\end{array}$ & $\begin{array}{l}\text { Natural grasslands / pastures / } \\
\text { agriculture }\end{array}$ & Grass & No similar group \\
\hline $\begin{array}{l}\text { 2.0: Evergreen shrubland (Quercus } \\
\text { evergreen, Poaceae) }\end{array}$ & $\begin{array}{l}\text { Transitional woodland-shrub / } \\
\text { broad-leaved forest / } \\
\text { sclerophyllous }\end{array}$ & $\begin{array}{l}\text { Warm temperate broad-leaved } \\
\text { evergreen }\end{array}$ & $\begin{array}{l}\text { Quercus-Chenopodiaceae- } \\
\text { Pistacia }\end{array}$ \\
\hline $\begin{array}{l}\text { 3.0: Pasture/wetland (Cyperaceae, } \\
\text { Poaceae, Quercus deciduous) }\end{array}$ & Moors and heathland & Cyperaceae & $\begin{array}{l}\text { Quercus-Pinus-sclerophyll } \\
\text { taxa }\end{array}$ \\
\hline 4.0: Pine forest (Pinaceae) & Coniferous forest / mixed forest & Boreal evergreen conifer & Pinus-Betula \\
\hline $\begin{array}{l}\text { 5.1: Pine woods (Pinaceae-Poaceae- } \\
\text { Quercus deciduous) }\end{array}$ & Coniferous forest / mixed forest & Boreal evergreen conifer & Pinus-Betula \\
\hline $\begin{array}{l}\text { 5.2: Pine steppe (Pinaceae-Poaceae- } \\
\text { Quercus deciduous-Artemisia) }\end{array}$ & Coniferous forest / mixed forest & No similar group & $\begin{array}{l}\text { Pine-Betula-Chenopodiaceae- } \\
\text { Quercus }\end{array}$ \\
\hline $\begin{array}{l}\text { 6.1: Deciduous oak woods (Quercus- } \\
\text { Poaceae-Pinaceae) }\end{array}$ & Broad-leaved forest & Temperate summer green & $\begin{array}{l}\text { Quercus-Pinus-sclerophyll } \\
\text { taxa }\end{array}$ \\
\hline $\begin{array}{l}\text { 6.2: Deciduous oak parkland (Quercus- } \\
\text { Poaceae-Pinaceae-sclerophyll taxa) }\end{array}$ & Broad-leaved forest & Temperate summer green & $\begin{array}{l}\text { Quercus-Pinus-sclerophyll } \\
\text { taxa }\end{array}$ \\
\hline $\begin{array}{l}\text { 7.0: Fir forest (Abies-Quercus } \\
\text { deciduous-Corylus-Pinaceae) }\end{array}$ & Coniferous forest / mixed forest & Boreal evergreen conifer & No similar group \\
\hline
\end{tabular}




\begin{tabular}{|l|l|l|l|}
\hline $\begin{array}{l}\text { 8.1: Alder woods (Alnus-Quercus } \\
\text { deciduous-Cyperaceae) }\end{array}$ & Broad-leaved forest & Temperate summer green & Corylus-Quercus-Alnus \\
\hline $\begin{array}{l}\text { 8.2: Coniferous forest (Picea-Pinaceae- } \\
\text { Abies) }\end{array}$ & Coniferous forest / mixed forest & Boreal evergreen conifer & Picea-Pinus-Betula \\
\hline $\begin{array}{l}\text { 8.3: Beech woods (Fagus-Quercus } \\
\text { deciduous-Poaceae-Corylus) }\end{array}$ & Broad-leaved forest & Cool temperate summer green & Fagus-Picea-Carpinus \\
\hline $\begin{array}{l}\text { 8.4: Mesic forest (Corylus-Quercus } \\
\text { deciduous-Poaceae-Pinaceae-Ulmaceae }\end{array}$ & Broad-leaved forest & Cool temperate summer green & Corylus-Quercus-Alnus \\
\hline
\end{tabular}

